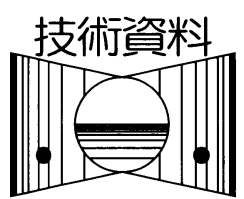

\title{
廃棄プラスチック再生残さ混合油における 着火性評価*
}

一第2報 セタン指数についての考察一

\begin{abstract}
近 藤 博 美** 河 野 高 秀** 増 田和 彦**
\end{abstract}

Evaluation of Ignition Characteristics on Blended Residual Oil Reclaimed from Waste Plastics:

Part 2, Cetane Index Consideration

By Hiromi Kondoh, Takahide Kawano, and Kazuhiko Masuda

In Part 1, to clarify the usability of residual oil reclaimed from waste plastics as diesel fuel, the authors evaluated the correlation between the result of FIA ignition test and the calculation result of JIS K2204 Cetane Index.

In this report, furthermore, referring to also the fuel density and the distillation characteristics of marine diesel oil, the authors considered the JIS K2204 and the JIS K2280 Cetane Index from ignition characteristics standpoint.

\section{1. まえがき}

廃棄プラスチックリサイクル技術の一つとして， 廃棄プラスチック油化技術がある。現在, 廃棄プ ラスチック再生残さ油を燃料油として活用する上 で，再生残さ油とA重油の混合油の着火性指標は 明らかではない。著者らは，ディーゼル燃料油と して廃プラスチック再生残さ油を有効に活用する ことを目的とし, 再生残さ油とA重油の混合油の FIA着火性試験 (FIAセタン価) 打よび中速ディーゼ ルエンジンを用いての燃焼実験を行った。 ${ }^{1)}$ 前報 ${ }^{2)}$ において，再生残さ混合油は，非常に良い着火特 性を持つことがわかった。またセタン指数 (JIS K2204）との比較を行い，その結果良い相関性があ ることがわかった。本報では，各燃料油性状の分 析結果と, JIS K2204抢よびJIS K2280セタン指数 の計算結果との相関性について調べた.

\section{2. 燃料油規格の現状}

廃棄プラスチック再生油の燃料油規格は現在な い. 表1はディーゼル燃料油の国内規格と国際規格 の概要を比較したものである．国内のディーゼル エンジンの燃料油についての品質規格として, JIS K2204 とJIS K2205がある。主として，自動車用に 使用する軽油について規定しているのがJIS K2204 である。重油について規定しているのがJIS K2205 である.ディーゼル燃料油の着火性指標 (自己着火 性）を表す数值としてセタン価がある。軽油に打け る規格のJIS K2204では，セタン指数で規定されて おり，「セタン指数はセタン価を用いることもでき る」ことが記載されている. JIS規定のセタン指数 の計算式はJIS K2204 (1992) から ISO規格の計算式 に改定され，JIS K2280（1996）において規定され ている。重油規格のJIS K2205には，七タン指数の 規格がない.ディーゼルエンジン用途の推奨規格 として，(社) 日本陸用内燃機関協会 (陸内協) と全 国漁業共同組合連合会 (全漁連) などがあり，これ らの推奨規格のセタン指数はJIS K2204（1992）に より求められている.

*原稿受付 平成 15 年 4 月 16 日

**正会員 ダイハツディーゼル株式会社

（滋賀県守山市阿村町45） 
表1 ディーゼル燃料油の国内規格と国際規格

\begin{tabular}{|c|c|c|c|c|c|}
\hline & \multicolumn{4}{|c|}{ 国内規格 } & 国際規格 \\
\hline & JIS K 2204 & JIS K 2205 & 陸内協推奨 & 全漁連規格 & ISO 8217 \\
\hline 適用 & 主に自動車用 & & 陸用エンジン & 漁船用 & 舶用エンジン \\
\hline 油種 & 2 号 & 1種1号 & & A重油 & DMA \\
\hline 項目 単位 & & & & & \\
\hline $\begin{array}{ll}\text { 密度 } & \mathrm{g} / \mathrm{cm} 3 \\
@ 15^{\circ} \mathrm{C} & \mathrm{kg} / \mathrm{m} 3\end{array}$ & & & $0.83-0.87$ & & 890 以下 \\
\hline $\begin{array}{r}\text { 動粘度 } 50^{\circ} \mathrm{C} \quad \mathrm{mm} 2 / \mathrm{s} \\
40^{\circ} \mathrm{C} \\
30^{\circ} \mathrm{C} \\
\end{array}$ & 2.5 以上 & 20以下 & $2.0-5.5$ & 5.5以下 & $1.5-6.0$ \\
\hline $\begin{array}{c}\text { 流動点 } \\
\text { 寒候用 } \\
\text { 暖候用 }\end{array}$ & -7.5以下 & $\begin{array}{l}5 \text { 以下 } \\
0 \text { 以下 } \\
10 \text { 以下 }\end{array}$ & -7.5 以下 & & $\begin{array}{l}-6 \text { 以下 } \\
\text { 0以下 }\end{array}$ \\
\hline 自詰り点 ${ }^{\circ} \mathrm{C}$ & -5 以下 & & -5.0以下 & (4グレード) & \\
\hline $\begin{array}{l}\text { セタン価 (セタン指数) } \\
\text { セタン指数 }\end{array}$ & 45以上 & & 45以上 & 45以上 & 40以上 \\
\hline 硫黄分 質量\% & 0.05以下 & 0.5以下 & 1.0以下 & 1.0以下 & 1.5以下 \\
\hline 90\%蒸留温度 ${ }^{\circ} \mathrm{C}$ & 350以下 & & 380以下 & & \\
\hline
\end{tabular}

セタン価(セタン指数):JIS K 2280 (1996)、 セタン指数:JIS K 2204 (1992)

上記比較表は一部の項目を省略。

\section{3. 試験燃料油 (廃プラスチック混合油) の性状}

図1に, 試験に用いた燃料油の分析結果を示す. 横軸に, 廃棄プラスチック再生残さ油 (RRO) とA重油 (MDO) の混合比率を表している. 試験燃料油は7種 類で, MDO および, RRO とMDOの混合比率を 20 , 40，50，60，80質量\%にした混合油 (B20，B40，B50, B $60, \mathrm{~B} 80)$ である.このRROの特徵として, 燃料密度 は, MDOの密度よりも小さい.一方, RROの流動点 は高く，常温においては流動しない.B80の動粘度

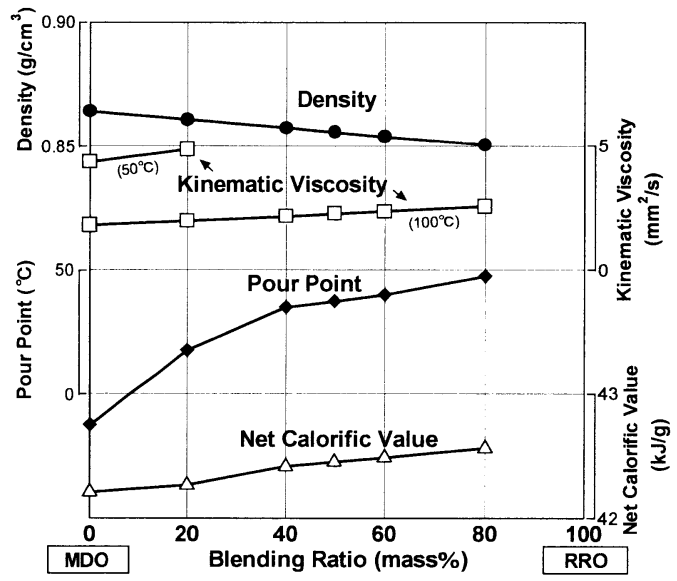

図1 RRO混合油の分析結果

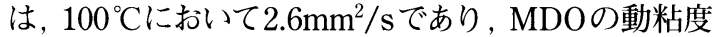
に比較してもそれほど大きくない，また，発熱量にお いては，B80の方がMDOよりも若干高かった。

\section{4. 舶用ディーゼル油燃料物性の検討}

4.1 密度と動粘度図 2 に, 密度と動粘度 $\left(50^{\circ} \mathrm{C}\right)$ の関係を示す。RRO混合油に用いた試験用 舶用ディーゼル油MDO (⿴)，および著者らが年間 入手した市販 $\mathrm{A}$ 重油のサンプル燃料を分析した結

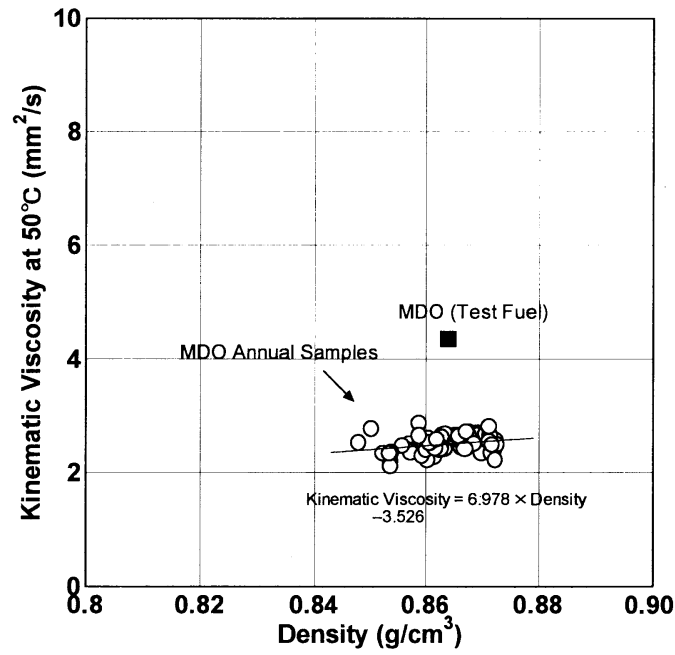

図2 密度と動粘度 (A 重油) 
果 $(\bigcirc)$ をプロットしている。サンプル燃料 $(\bigcirc)$ に おいて, 密度は, 約 $0.85 \sim 0.87 \mathrm{~g} / \mathrm{cm}^{3}$ の範囲で分布 している. 動粘度 $\left(50^{\circ} \mathrm{C}\right)$ は, $2.2 \sim 2.8 \mathrm{~mm}^{2} / \mathrm{s}$ の範 囲内で分布しており，密度に対する動粘度のばら つきは少ない，MDO（四）については，密度は $0.864 \mathrm{~g} / \mathrm{cm}^{3}$ でサンプル燃料 $(\bigcirc)$ と同等であるが, 動粘度は $4.36 \mathrm{~mm}^{2} / \mathrm{s}$ と高く, 共にA重油相当の燃 料油であるにもかかわらず, サンプル燃料 $(\bigcirc)$ の 密度, 動粘度の相関の傾向から大きく外れている.

4.2 セタン指数 (JIS K2204) と蒸留温度 (50\%) 図3に，セタン指数(JIS K2204) と50\%蒸留温度の 相関を示す。サンプル燃料 $(\bigcirc)$ においては, セタ ン指数 (JIS K2204) は約42～52の範囲に，50\%蒸留 温度は $270 \sim 290^{\circ} \mathrm{C}$ 範囲に分布している。セタン .指数 (JIS K2204)においては50\%蒸留温度が計算に 用いられているが，セタン指数 (JIS K2204) 計算結 果とのはっきりした相関はみられない．MDO については，セタン指数 (JIS K2204) は $58.5 ， 50 \%$ 蒸留温度は $328.5^{\circ} \mathrm{C}$ で，サンプル燃料 $(\bigcirc)$ の分布範 囲から大きく外れている.

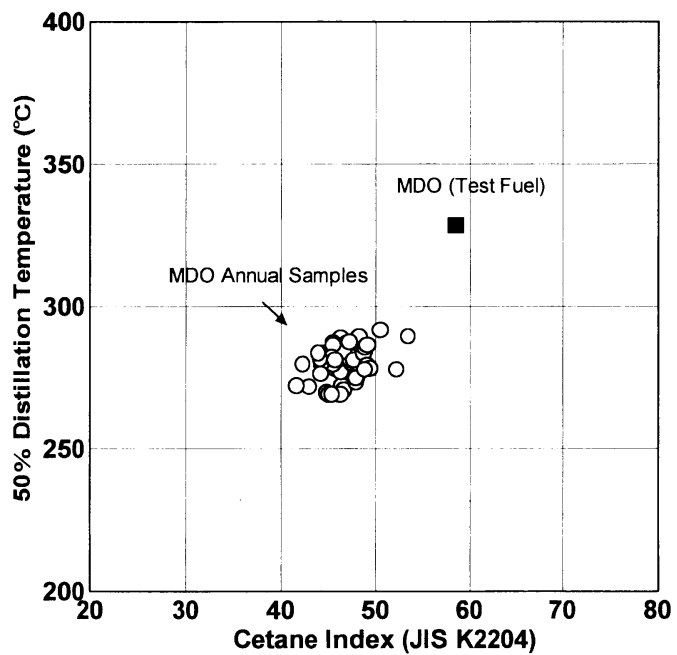

図3 セタン指数 (JIS K2204) と 50 \% 蒸留温度

4.3 セタン指数 (JIS K2280) と蒸留温度 (10, $50,90 \%$ ) 図 4 〜罒 6 に, 七タン指数 (JIS K2280) と $10 \% ， 50 \% ， 90 \%$ 蒸留温度の相関をそれぞ れ示す。サンプル燃料 $(\bigcirc)$ において，七タン指数 （JIS K2280）は約40～500範囲で分布している。ま
たセタン指数 (JIS K2280) では，10，50，90\%蒸留 温度が計算式に用いられているが，前述のJIS K2204の場合と同様，セタン指数 (JIS K2280) 計算 結果とのばらつきが大きい. MDO(ロ)は，セタン 指数 (JIS K2280) は48.8で, サンプル燃料 $(\bigcirc)$ の 分布範囲内にある。蒸留温度については $10 \%$ の場合 はサンプル燃料 $(\bigcirc)$ の範囲内にある。しかし， $50 \%$ おび $90 \%$ では $40^{\circ} \mathrm{C} \sim 50^{\circ} \mathrm{C}$ 高く，サンプル燃 料 $(\bigcirc)$ との間において蒸留特性が大きく異なって いることを示している。 また, MDO (ם)の90\%蒸 留温度は $400^{\circ} \mathrm{C} て ゙$, 表 1 の陸内協推奨の燃料油性状

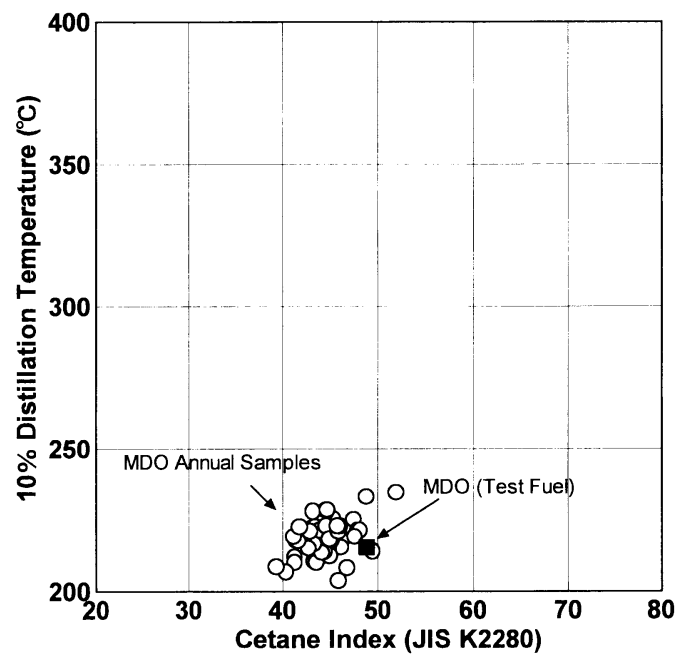

図4 セタン指数 (JIS K2280) と $10 \%$ 蒸留温度

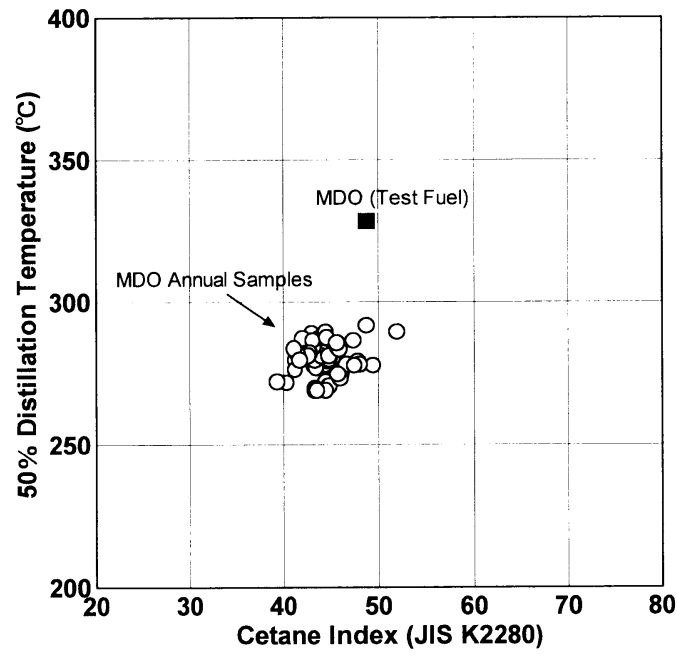

図5 セタン指数 (JIS K2280) と 50 \% 蒸留温度 


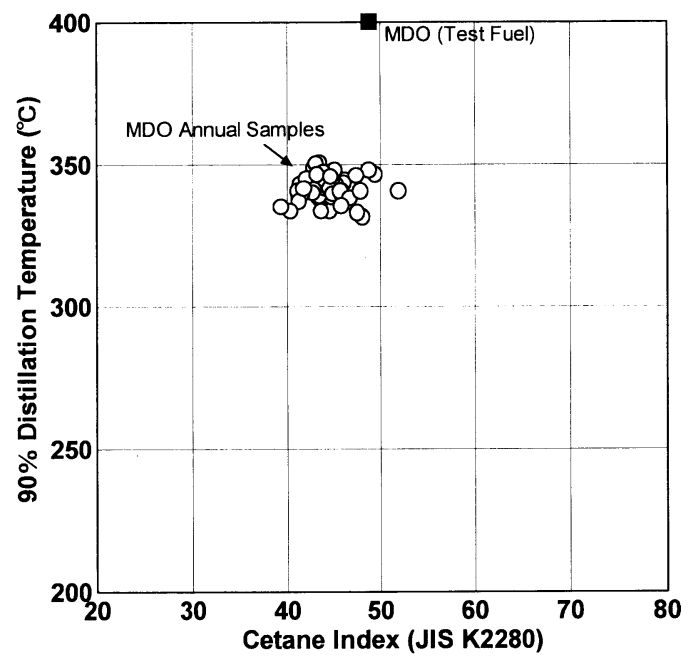

図6 セタン指数 (JIS K2280) と $90 \%$ 蒸留温度

条件 $380^{\circ} \mathrm{C}$ 以下を満たしていない。しかしながら， 他の性状（密度, 動粘度, 流動点, 目詰まり点, セタン指数, 硫黄分) については満足している.

4.4 セタン指数と密度 図7 と図8に, セタ ン指数 (JIS K2204 およびJIS K2280) と密度の相関 を示す。サンプル燃料 $(\bigcirc)$ において, JIS K2204, JIS K2280とも，燃料密度とセタン指数において高 い相関性が示されている。最小自乗法による結果 では, JIS K2204, JIS K2280とも, 密度 $0.01 \mathrm{~g} / \mathrm{cm} 3$ の低下で，七タン指数は約 5 程度の増加を示してい る. $\operatorname{MDO}(\boldsymbol{\square})$ のセタン指数は, サンプル燃料

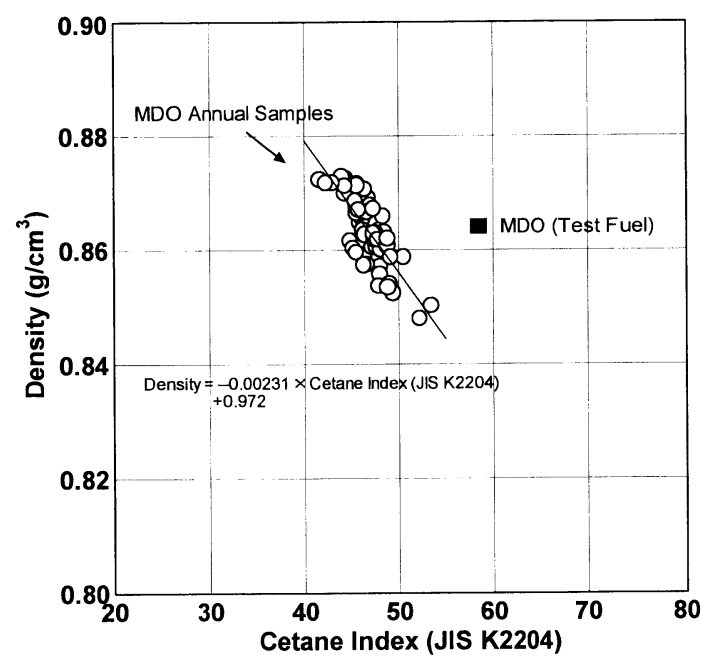

図7 セタン指数 (JIS K2204) と密度

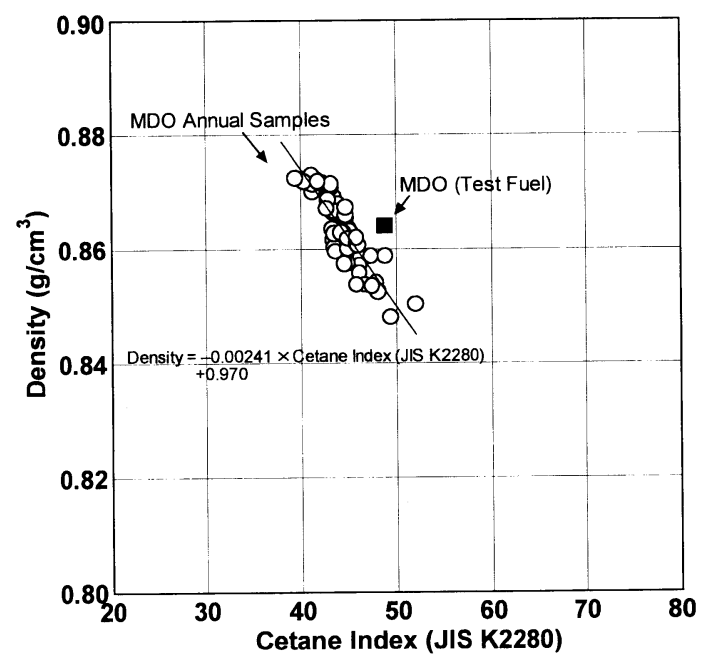

図8 セタン指数 (JIS K2280) と密度

（○）の相関線に対して, JIS K2204の場合は10程 度も高い。一方, セタン指数 (JIS K2280)の場合 は，5程度高いだけである。

\section{5. 廃プラスチック混合油の着火性}

5.1 セタン指数JIS K2204 とJIS K2280 図9 に，セタン指数JIS K2204 とJIS K2280の相関を示 す. サンプル燃料 (○)のセタン指数は, JIS K2280 はJIS K2204よりも約3高い程度で, 比較的良い相 関性を示している。一方, MDO（回）のタン指 数は, JIS K2204よりもJIS K2280の方が, 約10程

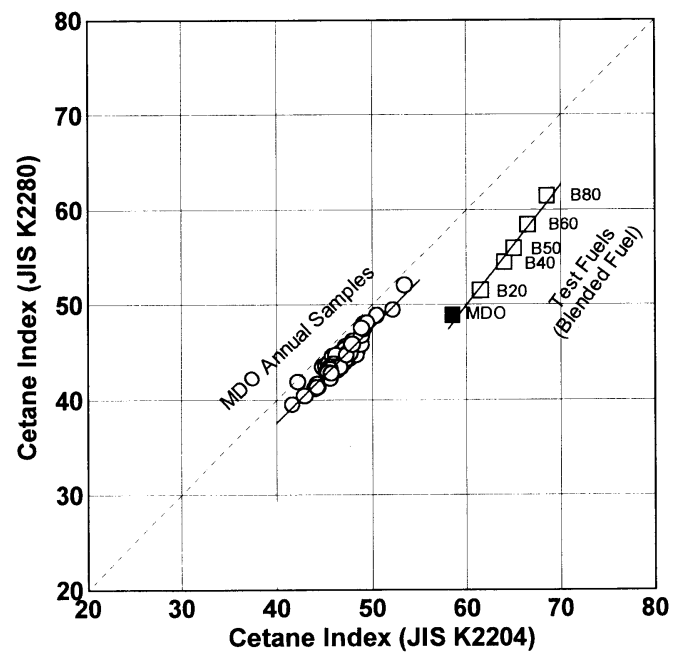

図9 セタン指数JIS K2204とJIS K2280 
度も低い.しかし, MDOとRROとの混合比率が 増加するにともない，わずかだがJIS K2204とJIS K2280との差は少なくなる傾向にある.

\section{2 セタン指数とFIAセタン価図10に,} $\mathrm{MDO}$ とRRO各混合油における, セタン指数 (JIS K2204 およびJIS K 2280) とFIAセタン価の相関を 示す. 本来, FIAセタン価は, JIS K2280セタン指 数と近い傾向を示すはずであるが, 本試験の範囲 内に扎てて, FIAセタン価は, JIS K2204セタン 指数との間に, 高い相関性が現れている。一方,

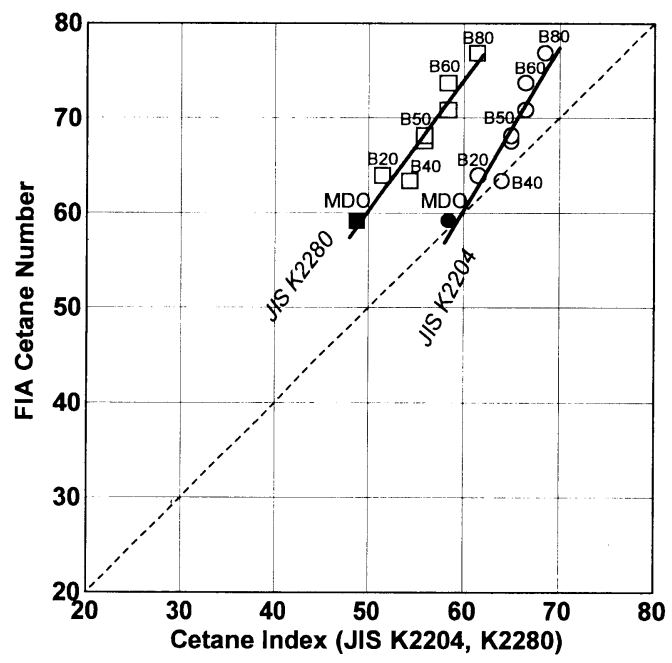

図10 セタン指数とFIAセタン価
JIS K2280セタン指数は, FIAセタン価と比較して, 10〜 15程度低い. 尚, RRO 混合油の $90 \%$ 蒸留温度 は計測不可であった。本解析では，50\%，70\%の蒸 留温度から外抻により $90 \%$ 蒸留温度を想定し， JIS K2280セタン指数計算を行った.

\section{6. まとめ}

本研究の範囲内において得られた知見を以下に 示す.

1）燃料油密度とセタン指数の間には，良い相関 性がある。

2）年間サンプルした市販A重油および廃プラスチ ック混合油試験で用いたA重油の間で, 燃料 性状およびJIS K2204, JIS K2280セタン指数 との相関性に扔いて，異なる傾向が示された。

3）本試験で用いた廃プラスチック混合油におい ては，FIAセタン価は，傾向は異なるが，JIS K2280，JIS K2204セタン指数ともに，良い相 関性があった。

\section{参考文献}

1) H.Kondoh et al.,23rd CIMAC Hamburg 2001, "Ignition and Combustion Characteristics of New Residual Oil Reclaimed from Waste Plastics", May 2001

2) 近藤ほか 2 名, 日マリ学誌, 37-11 (平14-11) 